
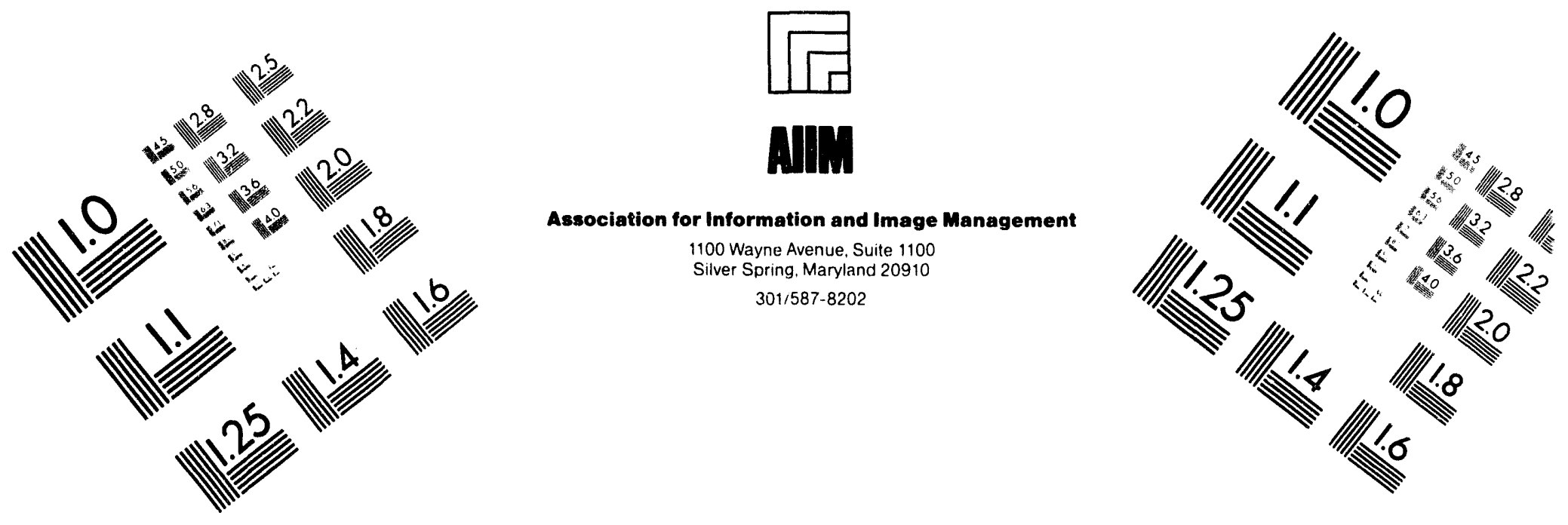

\title{
Centimeter
}

$\begin{array}{llllllllllllllll}1 & 2 & 3 & 4 & 5 & 6 & 7 & 8 & 9 & 10 & 11 & 12 & 13 & 14 & 15 & \mathrm{~mm}\end{array}$

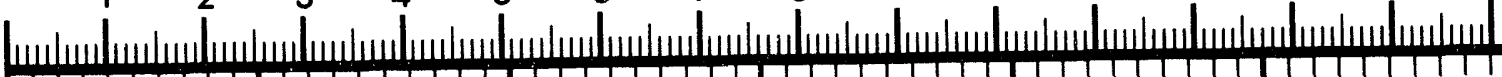

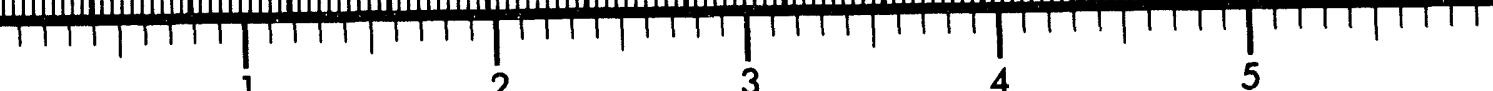
Inches
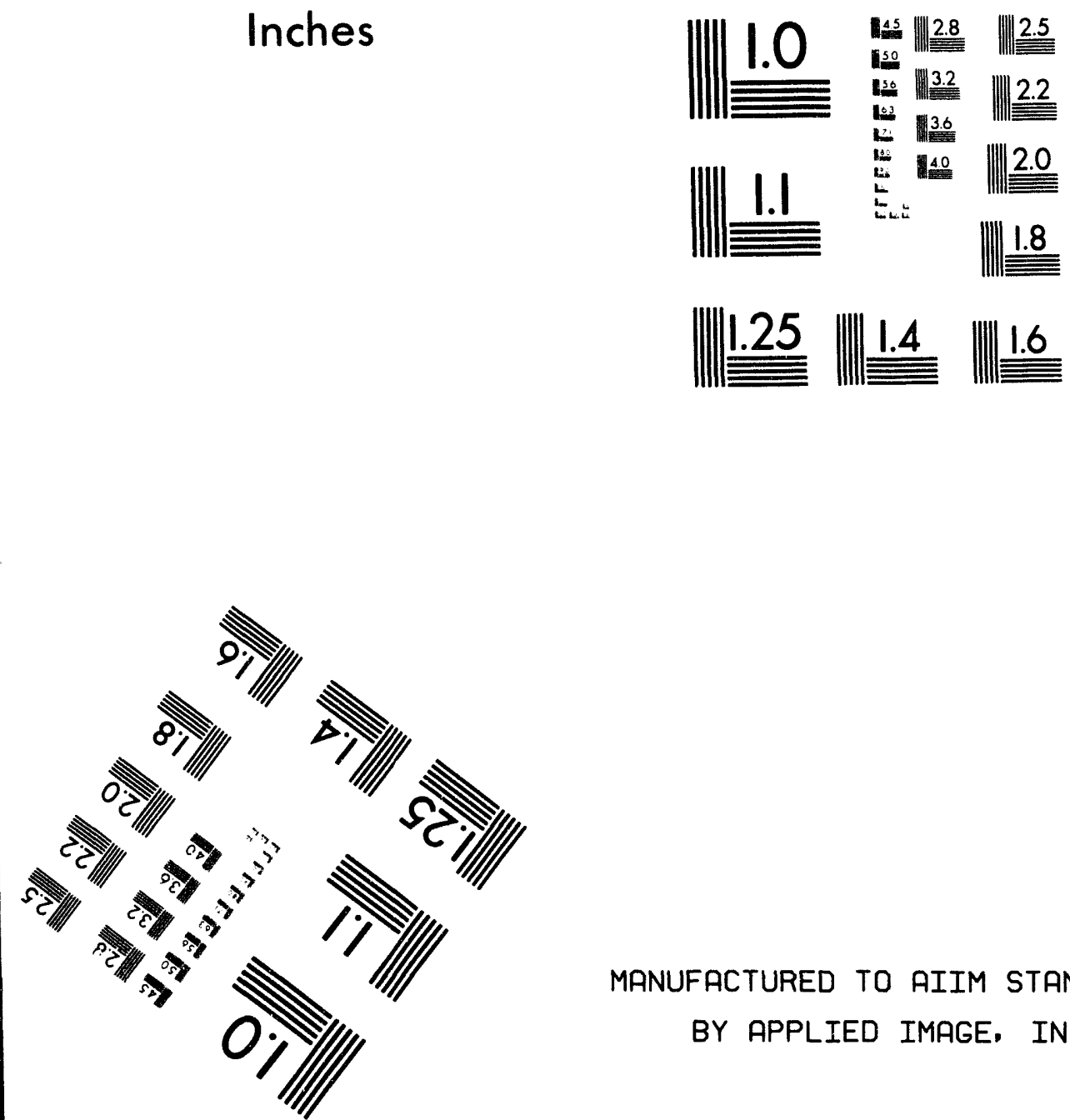

MANUFACTURED TO AIIM STANDARDS

BY APPLIED IMAGE, INC.

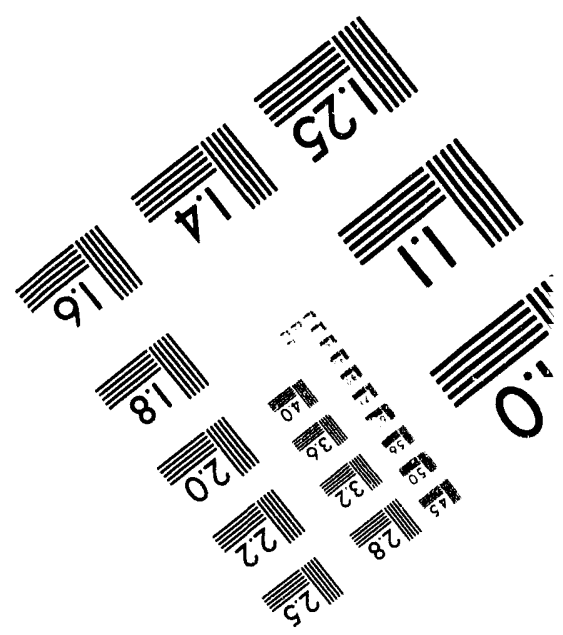



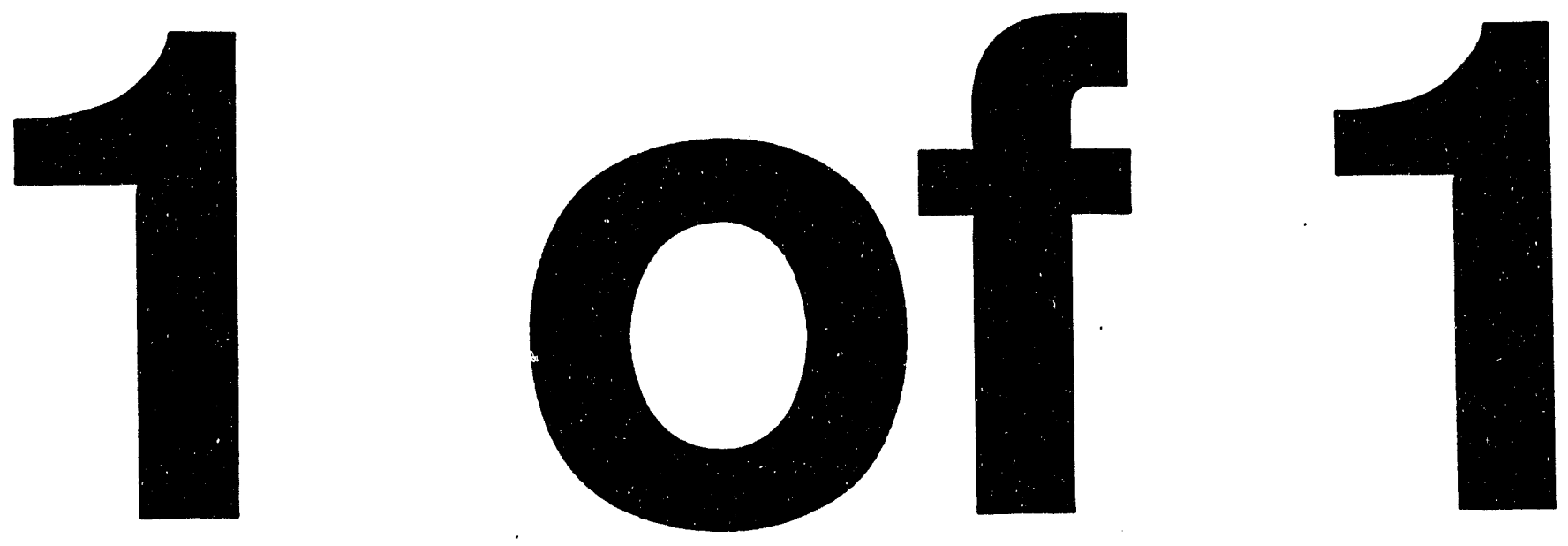


\section{Work Plan for Ground Water ELEVATION DATA RECORDER/MONITOR WELL INSTALLATION AT THE New Rifle Site, Rifle, Colorado}

\section{DISCLAIMER}

This report was prepared as an account of work sponsored by an agency of the United States Government. Neither the United States Government nor any agency thereof, nor any of their employees, makes any warranty, express or implied, or assumes any legal liability or responsibility for the accuracy, completeness, or usefulness of any information, apparatus, product, or process disclosed, or represents that its use would not infringe privately owned rights. Reference herein to any specific commercial product, process, or service by trade name, trademark, manufacturer, or otherwise does not necessarily constitute or imply its endorsement, recommendation, or favoring by the United States Government or any agency thereof. The views and opinions of authors expressed herein do not necessarily state or reflect those of the United States Government or any agency thereof. 
NOT INTENDED FOR PUBLIC RELEASE

This report has been reproduced from the best available copy.

Number of pages in this report: 17

For availability contact:

Office of Scientific and Technical Information

P.O. Box 62

Oak Ridge, TN 37831

(615) 576-8401 
WORK PLAN FOR GROUND WATER

ELEVATION DATA RECORDER/MONITOR WELL

INSTALLATION AT THE

NEW RIFLE SITE, RIFLE, COLORADO

August 1994

Prepared for

U.S. Department of Energy UMTRA Project Office

Albuquerque, New Mexico

Prepared by

Jacobs Engineering Group Inc.

Albuquerque, New Mexico 
Section

Page

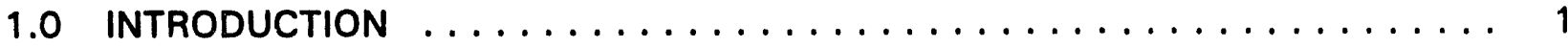

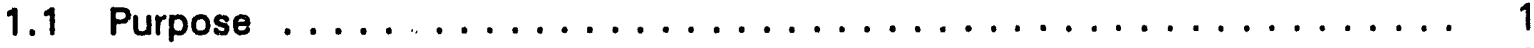

1.2 Data collection objectives ...................... 1

2.0 MONITOR WELL AND DATA LOGGER INSTALLATION TASKS . . . . . . . . 2

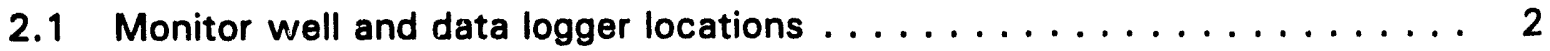

2.2 Permits, clearances, and access agreements ............... 2

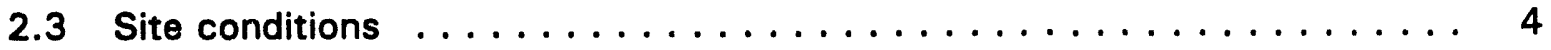

2.4 Well and data logger installation methods $\ldots \ldots \ldots \ldots \ldots \ldots \ldots \ldots$

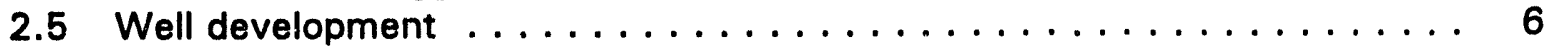

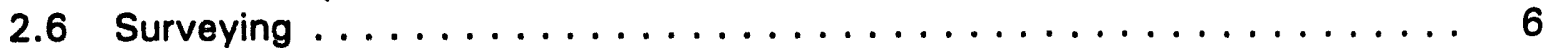

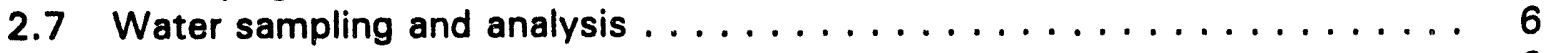

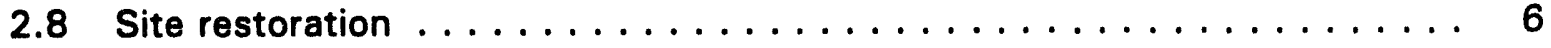

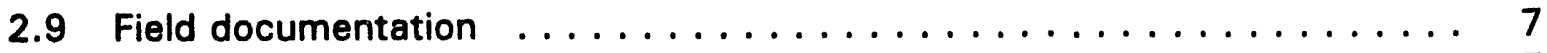

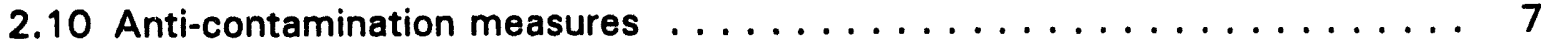

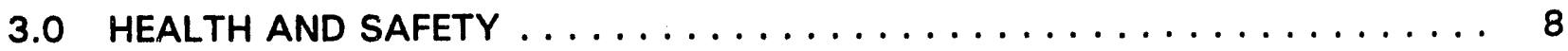

3.1 Local contingencies and contacts $\ldots \ldots \ldots \ldots \ldots \ldots \ldots \ldots \ldots \ldots$

3.2 Health and safety audits . . . . . . . . . . . . . . . . . 8

4.0 WELL AND DATA LOGgER INSTALLATION TASK SCHEDULE $\ldots \ldots \ldots$

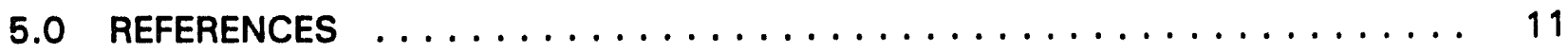




\section{LIST OF Fi GURES}

Figure

Page

1 Proposed monitor well and data logger location map, New Rifle, Colorado,

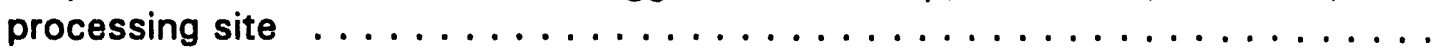

2 Route to hospital, Rifle, Colorado, site $\ldots \ldots \ldots \ldots \ldots \ldots \ldots$ 


\section{LIST OF ACRONYMS AND ABBREVIATIONS}

Acronym

Definition

$\mathrm{cm}$

DCO

centimeter

DOE

data collection objective

FORE

U.S. Department of Energy

$\mathrm{ft}$

FTR

field operation readiness evaluation

foot

field technical representative

m meter

PRS

project regulatory specialist

RAC

Remedial Action Contractor

SOP

standard operating procedure

TAC

UMTRA

Technical Assistance Contractor

Uranium Mill Tailings Remedial Action 


\subsection{INTRODUCTION}

\subsection{PURPOSE}

The purpose of this document is to describe the work that will be performed and the procedures that will be followed during installation of ground water monitor wells and ground water elevation data recorders (data loggers) at the New Rifle Uranium Mill Tailings Remedial Action (UMTRA) Project site, Rifle, Colorado. The monitor wells and data loggers will be used to gather required time-dependent data to investigate the interaction between the shallow aquifer and the Colorado River.

\subsection{DATA COLLECTION OBJECTIVES}

Data collection objectives (DCO) identify reasons for collecting data. The following are DCOs for the New Rifle ground water elevation data recorder/monitor well installation project:

- Long-term continuous ground water level data and periodic ground water samples will be collected to better understand the relationship between surface and ground water at the site.

- Water level and water quality data will eventually be used in future ground water modeling to more firmly establish numerical model boundary conditions in the vicinity of the New Rifle processing site.

- Modeling results will be used to demonstrate and document the potential remedial alternative of natural flushing. 


\subsection{MONITOR WELL AND DATA LOGGER INSTALLATION TASKS}

\subsection{MONITOR WELL AND DATA LOGGER LOCATIONS}

A maximum of three ground water monitor wells and four data loggers will be installed at the New Rifle site. Data loggers will be installed in the three new monitor wells (Wells RFN-0635, RFN-0636, and RFN-0637) and one existing monitor well (Well RFN-0590). The proposed locations of the monitor wells and data loggers are shown in Figure 1. Through flow net analysis using available ground water level data, the dominant ground water flow direction in the vicinity of the site was determined to be southwest. The new wells therefore are aligned from northeast to southwest, approximating the local ground water flow direction. The spacing of the wells should allow for detection of ground water level fluctuation in relation to river stage fluctuation throughout the year. The two wells closest to the river (wells 635 and 636) should show the greatest influence, while the third (well 637) and fourth (existing well 590) wells may show little or no influence from the river.

Annual hydrographs constructed from data obtained from the data loggers will approximate the extent of the river's influence on ground water flow in the uppermost aquifer near the river. Hydrographs will be used to help approximate when ground water discharge may be occurring to the river and when ground water flow likely parallels the river.

In the future, if the wells are sampled, changes in indicator parameters or concentrations of hazardous constituents will be used in conjunction with the hydrographs to help determine when and how much (if any) on-site natural flushing is occurring. Existing well 590, which will be equipped with a data logger, will be used to assess historical water quality trends as they relate to water quality data obtained from new downgradient wells.

In addition to the above criteria, placement was also based on site access conditions and constraints brought about by local construction activities and on-site surface remediation activities.

The data loggers will collect six water-level measurements per day at 4-hour intervals. Field technicians will download the recorded data to a personal computer and check the data logger for proper operation at approximately 3-month intervals.

\subsection{PERMits, CleARANCES, AND ACCESS AGREeMENTS}

A monitor well permit and access agreement are not needed for the installation of the data logger in existing well 590. Property Management has verified that existing access agreements are sufficient to allow the installation of data loggers in existing monitor wells. Proposed monitor wells RFN-0635, RFN-0636, and RFN0637 (Figure 1) will require access agreements prior to field work. These new monitor wells will also require monitor well permits. 

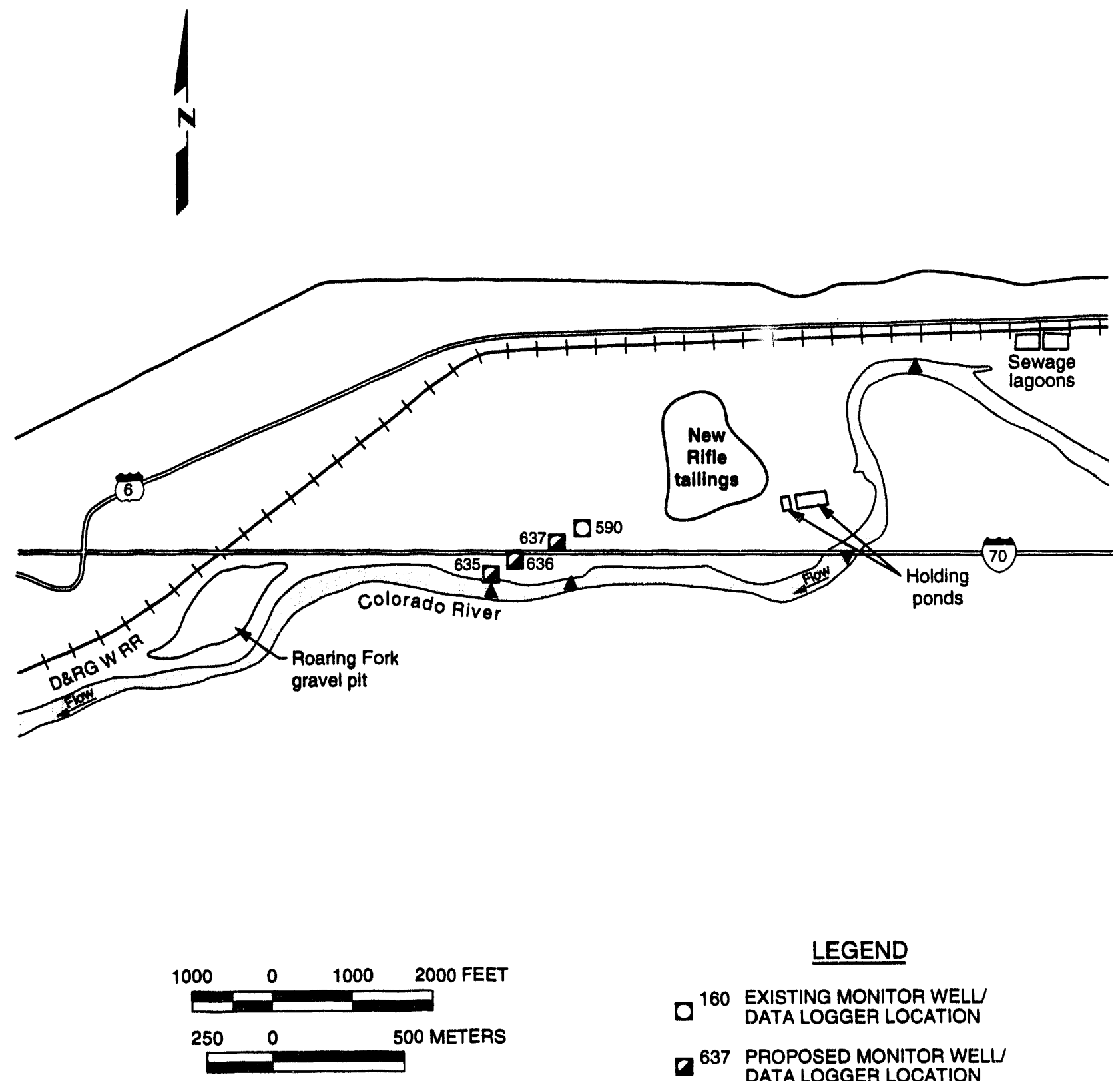

\section{LEGEND}

160 EXISTING MONITOR WELL DATA LOGGER LOCATION

637 PROPOSED MONITOR WELU DATA LOGGER LOCATION

(70) U.S. HIGHWAY

A RIVER LEVEL MEASURING POINT

$\nabla$ STAFF GAUGE LOCATION

FIGURE 1

PROPOSED MONITOR WELL AND DATA LOGGER LOCATION MAP NEW RIFLE, COLORADO, PROCESSING SITE 
The Colorado Division of Water Resources will be contacted by the project regulatory specialist (PRS) for permitting information. The PRS will apply for and obtain any necessary permits. Property Management will obtain any needed access agreements before any field work is initiated.

\subsection{SITE CONDITIONS}

Based on field observations during regular ground water sampling, the depth to the water table near the Colorado River is anticipated to be within 10 feet $(\mathrm{ft})(3$ meters [m]) of land surface. Well logs from monitor wells close to the river show that the surficial aquifer materials consist of medium- to fine-grained sand, with some clay and silt. A high percentage of cobbles are present in alluvial material. Usually, the percentage of cobbles increases abruptly near the water table. The underlying, semiconfined Wasatch Formation is usually encountered between 10 to $30 \mathrm{ft}$ ( 3 to $9 \mathrm{~m}$ ) below land surface.

\subsection{WELL AND DATA LOGGER INSTALLATION METHODS}

Because of the heterogeneous nature of the aquifer materials and the presence of cobbles, the air rotary casing advance drilling method will be used to install monitor wells at the site. Monitor wells will be installed according to UMTRA Project standard operating procedure (SOP) 14.3.1 (JEG, n.d.). Each shallow well will be approximately 15 to $20 \mathrm{ft}(4.5$ to $6 \mathrm{~m})$ deep and consist of approximately $5 \mathrm{ft}(2 \mathrm{~m})$ of 4-inch (10-centimeter [cm])-diameter PVC well screen and approximately 10 to $15 \mathrm{ft}(3$ to $4.5 \mathrm{~m})$ of 4 -inch $(10-\mathrm{cm})$-diameter PVC casing. The wells will be drilled to the top of the bedrock, and the screen will be set above the bedrock. Well construction materials and hand tools will be supplied by a licensed well driller contracted through Jacobs Engineering Group Inc., the Technical Assistance Contractor (TAC).

Data loggers and pressure transducers will be installed and calibrated in each monitor well following the manufacturer's instructions. Data loggers will be suspended in the monitor well for approximately 30 minutes to allow for cable stretch, water level equalization, and proper temperature equilibration between the ground water and data logger. Proper data logger operation will be verified by comparing the water level reading given by the data logger to the actual water level reading determined with a water level probe. Length of transducer cable will vary depending on depth to water and anticipated water level fluctuations in the monitor well. Existing ground water data, such as depth to water and historical water level fluctuations, will be reviewed to ensure data loggers and pressure transducers are installed so that the instruments operate properly throughout the year.

To verify proper data logger operation, data loggers will be checked immediately after installation by field personnel. Approximately 2 weeks after installation, the data logger operation will again be verified by field personnel. Once proper data 
logger operation is ensured, data will be downloaded at approximately 3-month intervals.

In addition to the SOPs mentioned above, the following applicable SOPS (JEG, n.d.) will be followed during monitor well and data logger installation:

14.1.2 Instructions for Field Technical Representative

14.1.3 Drilling and Test Pit Technical Representative

14.1.4 Verification of Grout Mix for Monitor Wells

14.1.5 FTR Daily Diary

14.1.6 Procedures for Completing the Daily Field Activity Report

14.1.7 Field/Off-Site Procurement of Supplies \& Services

14.3.1 Drilling Procedures

14.4.1 Soil and Rock Core Borehole and Test Pit Logging

14.4.2 Preparation of Logs for UMTRAP Documents

16.1.1 Monitor Well Installation

16.1.2 Well Development

16.1.19 Permitting Procedures for Installation or Decommissioning of Monitor Wells

16.1.22 Controlled Disposal of Potentially Contaminated Materials or Memorandum from Don Metzler to Clinton Smythe entitled "Evaluating Drill Cuttings and Well Development and Purge Waters"

17.4.1 Location ID for Test Borings, Test Pits, and Monitoring Locations

Internal communications will be maintained between the field representatives, site hydrogeologists, the TAC Contracts Department, Property Management, the site manager, and the U.S. Department of Energy (DOE). Before any installation of wells or data loggers occurs, the Remedial Action Contractor (RAC) site manager will be notified of the upcoming activities, and the work party will check in with the RAC. Any problems or complications encountered during field work will be reported to the TAC site manager, who will forward the information to the DOE. 


\subsection{WELL DEVELOPMENT}

No sooner than 48 hours after new monitor well completion, the well will be developed per UMTRA Project SOP 16.1.2 (JEG, n.d.) until the discharge is clear. The amount of water removed and approximate well yields will be recorded. The appropriate procedures will be followed to ensure proper disposal of development water.

\subsection{SURVEYING}

After installation, the new monitor wells will be surveyed by a local surveying contractor to establish top-of-casing elevation and Colorado state plane coordinates. The surface water elevation of the Colorado River as close as possible to the monitor well nearest the river (RFN-0635) and at two other locations along the Colorado River (Figure 1/ will be surveyed.

If ground water elevations in wells nearest the river and river elevations are significantly different, one staff gauge will be installed along the river. The staff gauge, if necessary, will be attached to the Interstate 70 bridge located approximately 0.5 mile ( 0.8 kilometer) east of the proposed monitor well locations (Figure 1). The river stage level on the staff gauge will be recorded at the time of surveying and every 3 months when data are downloaded from the data loggers. The river levels may be resurveyed periodically to ensure they correspond to the level being read on the staff gauge.

The river and the new wells nearest the river will be surveyed as close together in time as feasible, and water level readings taken as quickly as possible from the wells. The rest of the monitor well network will be measured after these data are collected. In this manner, representative water levels from the river and the shallow aquifer can be obtained that will be useful in assessing the future data collected by the data loggers. Monitor well top-of-casing and river surface elevations will be surveyed to the nearest $0.01 \mathrm{ft}(3$ millimeters $)$.

\subsection{WATER SAMPLING AND ANALYSIS}

No water quality samples will be taken at this time, although the wells may be sampled in the future.

\subsection{SITE RESTORATION}

Moderate site disturbance is anticipated. However, areas of disturbed soil will be raked smooth by hand, all trash will be collected immediately, and established roadways and paths will be used whenever possible. 


\subsection{FIELD DOCUMENTATION}

In addition to the daily diary kept by the field technical representative (FTR), the following documentation will be compiled and data collected:

- The monitor well locations will be photographed and located on a map. The elevations of the top-of-casing for each well point and the surface water elevations will be surveyed by the surveying subcontractor.

- Surface water elevation measuring points at the edge of the Colorado River will be surveyed with respect to the top-of-casing of the nearest monitor well.

- Water level measurements at each new well and from each existing monitor well will be recorded at least once just before the data loggers are set to begin logging in the wells.

- Proper functioning of the data loggers will be verified by recording the depth to water as reported by the data logger and a water level probe.

Copies of all pertinent field documentation will be maintained in the UMTRA Project Document Control Center.

\subsection{ANTI-CONTAMINATION MEASURES}

Before being taken onto the site, all well installation materials, including the drill rig, will be cleaned to the FTR's satisfaction as required. The TAC FTR will inspect equipment for the presence of hydraulic oil or grease, and, if necessary, the equipment will be steam cleaned to remove such material. To minimize rig decontamination, the wells will be drilled in order from areas of lowest to highest ground water contamination. The drilling rig will be steam cleaned prior to moving to the next drilling location. At the New Rifle site, the drilling sequence is anticipated to be RFN-0635, RFN-0636, and RFN-0637. 


\subsection{HEALTH AND SAFETY}

\subsection{LOCAL CONTINGENCIES AND CONTACTS}

All personnel involved with monitor well and data logger installation will have the following equipment:

- Hard hat.

- Steel-toed boots.

- Safety glasses.

- Work gloves.

- Sunblock lotion.

- Fresh drinking water.

The following items will be on the site:

- First-aid kit.

- Fire extinguisher.

- Cellular telephone.

The location of the nearest hospital in case of emergency is Clagett Memorial Hospital (303-625-1510) located at 701 E. 5th Street, Rifle, Colorado (Figure 2). The phone number for all emergencies is 911 .

\subsection{HEALTH AND SAFETY AUDITS}

The time on-site of the drilling contractor is likely to be less than 5 days, and it is not anticipated that an audit will be required. However, the FTR will be responsible for observing that subcontractor personnel work activities are in compliance with UMTRA Project health and safety requirements and that Occupational Safety and Health Administration codes 29 CFR Parts 1910 and 1926 (1994) are followed during all phases of well installation. The applicable SOPs (JEG, n.d.) are as follows:

\subsubsection{Occupational Safety and Health Complaints}

7.3.2 Occupational Safety and Health Complaints for TAC Subcontractors

14.1.2 Instructions for Field Technical Representative 


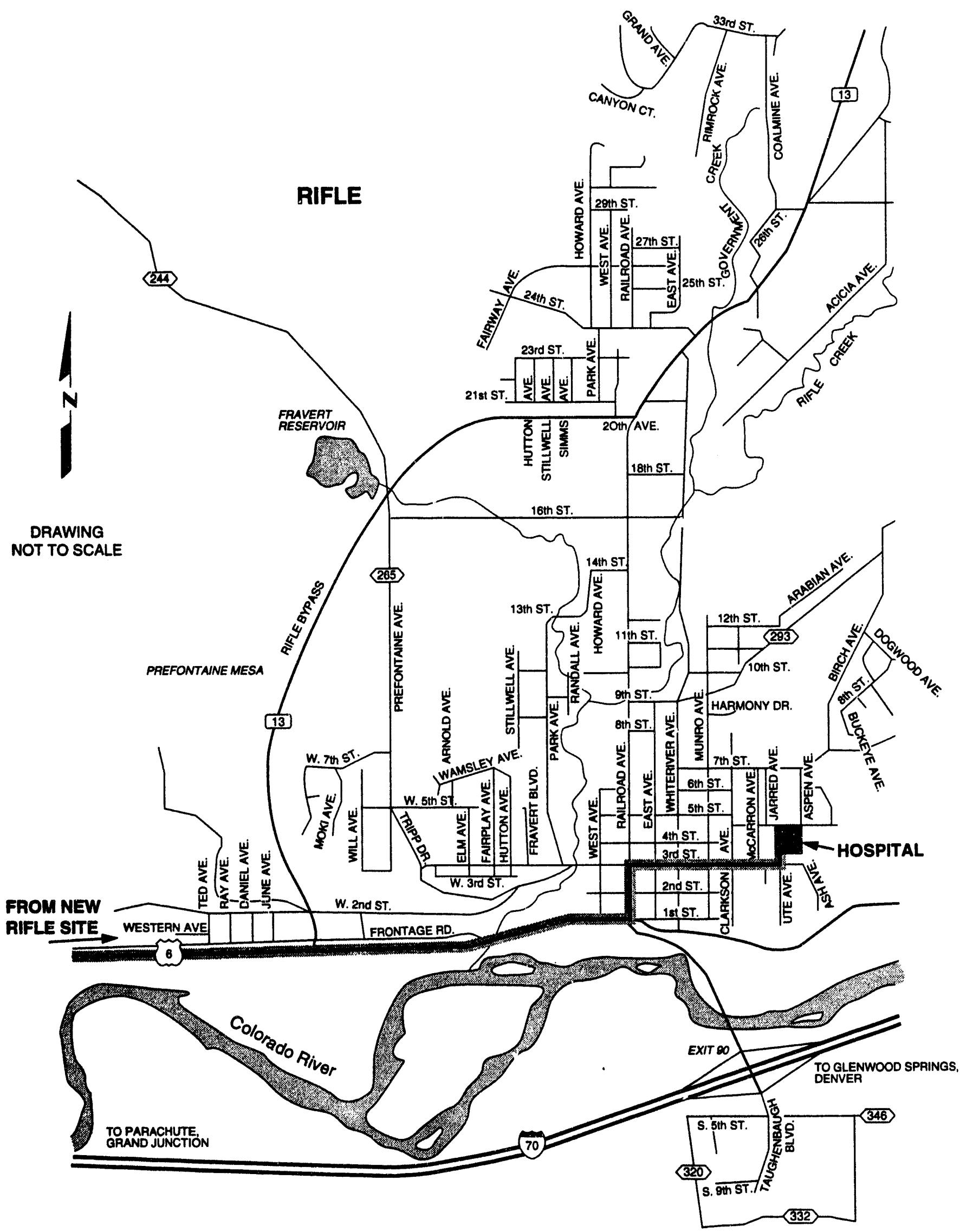

FIGURE 2

ROUTE TO HOSPITAL

RIFLE, COLORADO, SITE 


\subsection{WELL AND DATA LOGGER INSTALLATION TASK SCHEDULE}

The activities discussed in this work plan are part of a larger effort to install new monitor wells and data loggers at the Gunnison, Rifle, and Grand Junction sites. The same drilling contractor will be used at all three Colorado sites. To minimize mobilization fees, the drilling contractor, upon completion of well installation procedures, will move directly to the next site. The drilling schedule for the Rifle sites will depend on completion of drilling operations at the Gunnison site.

The tasks and accompanying tentative completion dates for this work plan are as follows:

Task

Site visit

Well permits

Access agreements

Award drilling subcontract

Conduct field operation readiness evaluation (FORE)

Equipment procurement

Install wells

Install staff gauge (if required)

Survey wells and river

Install data loggers

Check data logger operation
Completion

July 8

August 15

August 15

August 21

August 31

September 16

September 26

October 4

October 5

October 5

November 2 


\subsection{REFERENCES}

JEG (Jacobs Engineering Group Inc.), n.d. Albuquerque Operations Manual, standard operating procedures, prepared by Jacobs Engineering Group Inc., Albuquerque, New Mexico, for the U.S. Department of Energy, UMTRA Project Office, Albuquerque Operations Office, Albuquerque, New Mexico..

\section{CODE OF FEDERAL REGULATIONS}

29 CFR Part 1910, Occupational Safety and Health Standards, Occupational Safety and Health Administration, Department of Labor (1994).

29 CFR Part 1926, Safety and Health Regulations for Construction, Occupational Safety and Health Administration, Department of Labor (1994). 

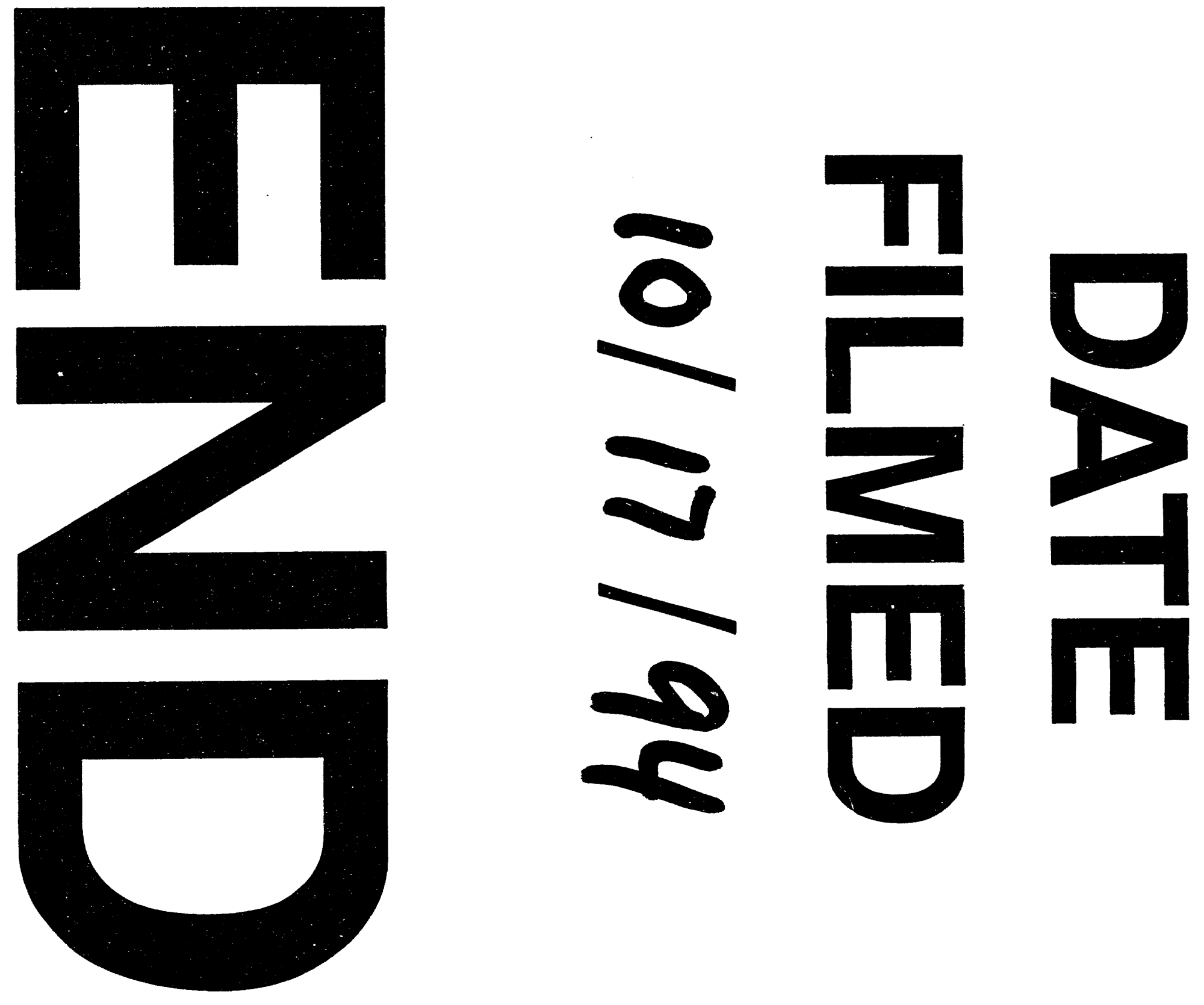
